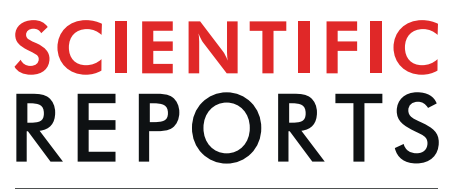

natureresearch

\title{
OPEN Author Correction: A novel transcription factor-like gene SbSDR1 acts as a molecular switch and confers salt and osmotic endurance to transgenic tobacco
}

\author{
Vijay Kumar Singh, Avinash Mishra, Intesaful Haque \& Bhavanath Jha \\ Correction to: Scientific Reports https://doi.org/10.1038/srep31686, published online 23 August 2016
}

This Article contains an error in the Methods section, under subheading 'Abiotic stress treatments and evaluation of transgenic lines', where:

"Plants (transgenic and WT) grown in plastic cups (for 30 days in green house under control condition) were shifted to controlled field condition and allow to grow further for 30 days."

should read:

"Plants (transgenic and WT) grown in plastic cups (for 30 days in green house under control condition) were shifted to controlled field condition (in green house; not open field) and allowed to grow further for 30 days."

(c) (i) Open Access This article is licensed under a Creative Commons Attribution 4.0 International (c) License, which permits use, sharing, adaptation, distribution and reproduction in any medium or format, as long as you give appropriate credit to the original author(s) and the source, provide a link to the Creative Commons license, and indicate if changes were made. The images or other third party material in this article are included in the article's Creative Commons license, unless indicated otherwise in a credit line to the material. If material is not included in the article's Creative Commons license and your intended use is not permitted by statutory regulation or exceeds the permitted use, you will need to obtain permission directly from the copyright holder. To view a copy of this license, visit http://creativecommons.org/licenses/by/4.0/.

(C) The Author(s) 2020 